Article

\title{
Sustainability in Italian Ceramic Tile Production: Evaluation of the Environmental Impact
}

\author{
Giacomo Boschi ${ }^{1,2} \mathbb{D}$, Giulia Masi ${ }^{2}$, Giuliana Bonvicini ${ }^{1}\left(\mathbb{D}\right.$ and Maria Chiara Bignozzi ${ }^{1,2, *}$ \\ 1 Centro Ceramico, 40138 Bologna, Italy; giacomo.boschi5@unibo.it (G.B.); bonvicini@centroceramico.it (G.B.) \\ 2 Department of Civil, Chemical, Environmental and Materials Engineering, University of Bologna, \\ 40131 Bologna, Italy; giulia.masi5@unibo.it \\ * Correspondence: maria.bignozzi@unibo.it; Tel.: +39-051-2090342
}

Received: 15 November 2020; Accepted: 16 December 2020; Published: 18 December 2020

\begin{abstract}
Sustainable development has recently become the driving force of all the policies leading environmental, economic, and social aspects of our life. In the construction sector, a large number of technological innovations has been introduced thus leading to an assessment of the environmental impact of the production processes. In the present study, the environmental impact of the Italian ceramic tiles production is analyzed and discussed. The evolution trends of the main atmospheric pollutants and the management of water and solid wastes of ceramic tile plants have been investigated over a period greater than 10 years, considering three different layouts of production cycles. The current evaluation shows that the Italian ceramic tiles industry has considered the environmental assessment as a fundamental practice for its development since the late 1980s. The reported data prove the high level of excellence reached by the Italian ceramic tile production and demonstrate how attention to the environmental impact is a fundamental key for the ceramic tile sector.
\end{abstract}

Keywords: ceramic tiles; environmental impact; air quality; best available techniques; pollutants; gaseous emissions; recycling; circular economy

\section{Introduction}

Sustainability has recently become a very popular topic and is currently relevant, strongly changing the environmental, economic, and social vision of the world. The concept of sustainability emerged during the late 1980s as a consequence of important debates at global level; it was defined as the development of the existing society which would be able to preserve the needs of future generations [1]. In this context, the whole industrial manufacture, energy production and consumption had to comply with rigorous legislations, so as to reduce their impact on the environment and consequently on the society, providing, thus, a more sustainable economic development. Construction materials is one of the biggest industrial sectors, and in recent years a lot of actions have been implemented to improve the sustainability in this field. Over the last two decades, strong innovations have been introduced in the construction materials production and in the assessment of the environmental impact of new constructions and architectures [2]. Global issues, such as urban heat island effect, city overpopulation and uncontrolled level of greenhouse gas emissions, have pushed the building sector to find alternative and innovative solutions [3-6].

Together with concrete, steel, glass and wood, ceramic is one of the most used building materials. Ceramics are inorganic and non-metallic materials mostly employed in buildings as wall, floor, and roof tiles or in mosaics. In addition, due to the low production costs, high physical and chemical properties, biocompatibility and their peculiar aesthetical features, ceramic materials are also used to produce tableware, sanitaryware, artistic sculptures, etc. However, in the building sector, ceramic tiles are industrial products characterized by the largest production and relevant economical value. 
Focusing on ceramic tiles, amongst the world competitors, the Italian industry is deeply involved in the environmental impact assessment and its efforts constantly aim at the improvement of the sustainability of the production processes $[7,8]$. In addition, the ceramic tile industry is of great importance for the Italian economy and society; the economic impact of this sector consisted of revenue of almost 5 billion euro in 2018 [9]. In the same year, Italy was rated as the sixth world ceramic tile producer, as the second in Europe, with 416 million square meters of manufactured tiles $(79 \%$ of that assigned to export) [10].

The two biggest European ceramic clusters are located in Spain and Italy, respectively in the Castellón (Valencia) and Sassuolo (Modena) districts. Due to the extremely high concentration of productive plants in those regions, the quality of air has been constantly monitored and a strong awareness toward the environmental impact of the production processes has surely increased in recent years. A wide number of scientific studies and analytical surveys have been carried out in order to evaluate the air quality and study the meteorological events affecting the pollution levels in those areas [11-13]. The Sassuolo district expands over the Modena and Reggio-Emilia provinces and supplies over $80 \%$ of the whole Italian ceramic tiles production. In 1978 , the influence of pollutant emissions was correlated to the pollutant concentration profiles recorded at ground level, thanks to extensive research on the climatic condition of the territory [14]. These studies allowed the quantification of the pollutant emission limits for an optimized compliance to the environmental quality standards of that period.

Since then, air quality of the Italian district has been constantly monitored [7,15-17]. In particular, the control of the emission flows and the improvement of the existing limits have been carried out through the updating of the Ceramic BRef (Best Available Techniques Reference Document) [18]. BRefs are the European Commission tool listing the Best Available Techniques (BAT) in accordance with the current level of technological innovation for each specific industrial sector. The BAT for the ceramic industry are the best practicable actions, approved by legislators and regulators, for meeting sustainability standards in this sector. The latest version of the Ceramic BRef dates to 2007 while an updated version of the document is now under revision. In addition, another important tool for the assessment of the environmental impact of products and services is Ecolabel, a European certification that sets strict limits and standards to atmospheric emissions and to the waste management from productive plants. Ecolabel also considers all the possible environmental and health concerns related to a specific product. The current version of the "Hard Coverings Ecolabel" related to the ceramic tiles production will last until June 2021 while the draft of the revised version is in progress [19]. Other acts and regulations are often endorsed within the EU's Member States, in order to improve the sustainability standards of the production processes. For example, in Italy, the ministerial decree D.M. 29/01/2007 establishes the Best Available Techniques (BAT) adopted by the Italian ceramic tile industry, especially considering the limits for atmospheric emissions [20]. This broad legislative scenario reflects the different levels of environmental policies existing in Europe, leading to different levels of industrial technology that can be applied. Moreover, the comparison between specific regulations and data collections regarding pollution can often be difficult and complex.

The aim of this study was to analyze the environmental impact of Italian ceramic tile production with particular attention on atmospheric emissions and waste material flows (Figure 1). In particular, specific attention has been paid to the management of water and solid wastes and on the following pollutant emissions: particulate matter $(\mathrm{PM})$, fluorine $(\mathrm{F})$, lead $(\mathrm{Pb})$, volatile organic compounds (VOCs), aldehydes and nitrogen oxides $\left(\mathrm{NO}_{\mathrm{X}}\right)$. Indeed, these are currently the most relevant pollutants related to the ceramic tile production thus representing the parameters to take under control for the improvement of air quality and sustainability in ceramic districts. The reported data represent the trends of environmental indicators collected from 1996 to 2018 in the Italian ceramic district. 


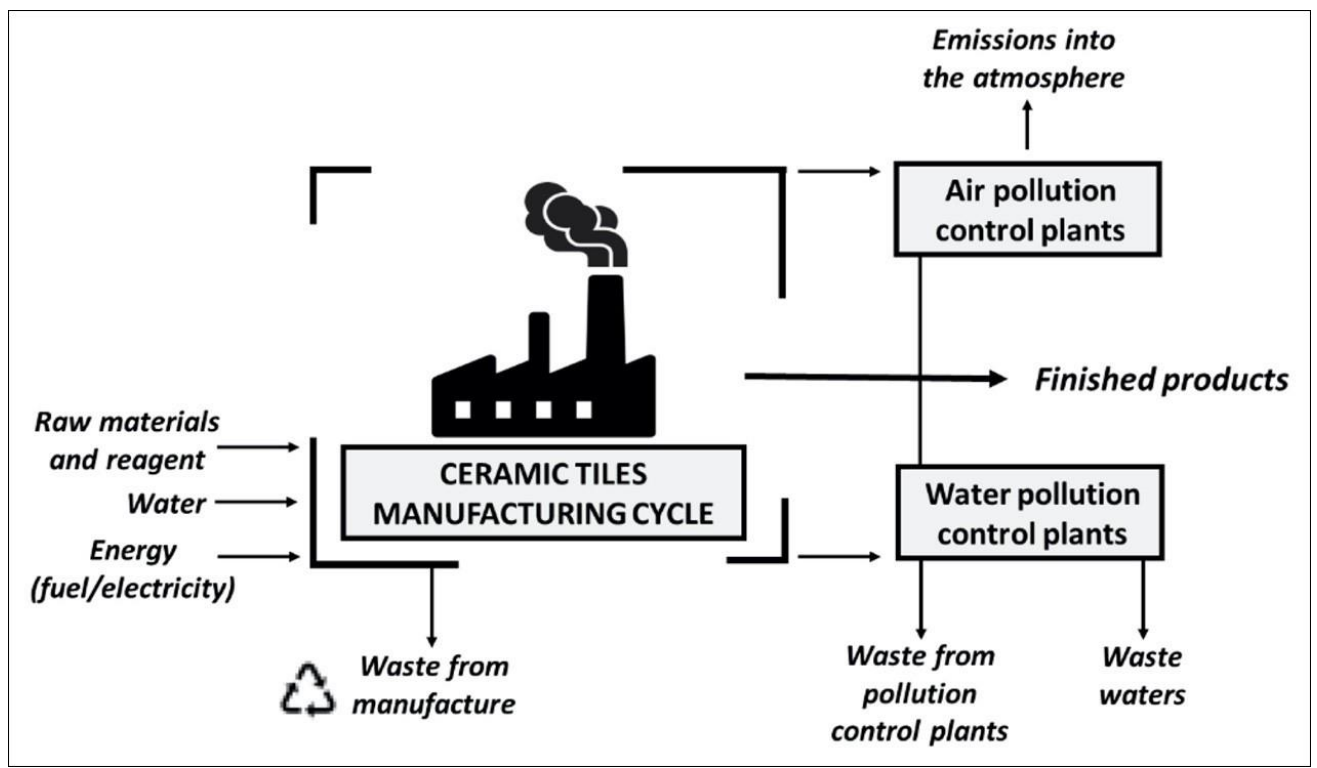

Figure 1. Materials, waste and emissions flows in ceramic tiles production plant.

\section{Materials and Methods}

\subsection{Materials and Production Process}

The main constituents of ceramic materials are clays, quartz and fluxing agents. Clays are a mixture of hydrous aluminum phyllosilicates forming compact grains characterized by particles of micrometric dimensions. Quartz is usually under the form of sand, while calcium carbonate and feldspars are used as fluxing agents [21-23]. The choice of the fluxing agent has a direct effect on firing temperature and open porosity of final products (e.g., feldspars allow porcelain tiles characterized by water absorption lower than $0.5 \%$ to be obtained). The ceramic tile production process can be defined as a powder technology, since all the applied raw materials are in the form of powders. For porcelain stoneware tiles, representing the top quality and most commercialized product in Europe, the production process is schematically described in Figure 2 with an indication of the main pollutants generated in each step.

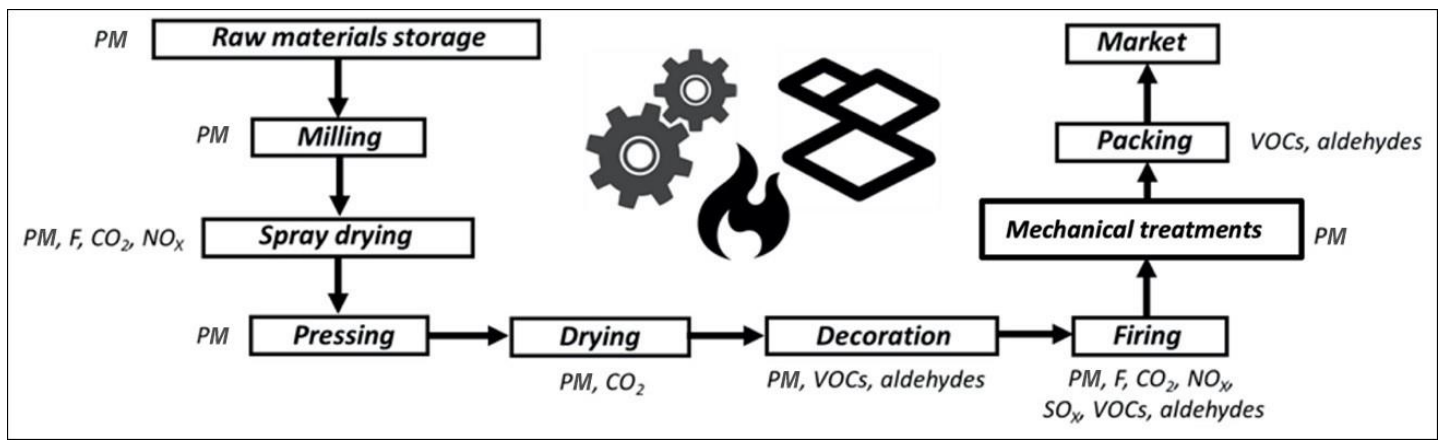

Figure 2. Scheme of the production stages for porcelain stoneware tiles and indication of the main pollutants generated in each step (PM: particulate matter; F: fluorine, $\mathrm{CO}_{2}$ : carbon dioxide; $\mathrm{NO}_{\mathrm{X}}$; nitrogen dioxides; VOCs: volatile organic compounds; $\mathrm{SO}_{\mathrm{X}}$ : sulfur dioxide).

In particular, raw materials are extracted from quarries and transported to production sites by land or sea. Here, they are grinded and wet milled to form a ceramic slurry, in which pigments can be also added to give colored bodies. Then, there is the spray-drying phase, where the slurry is treated to form rounded ceramic granules ready to be efficiently pressed. After pressing, the residual humidity is lowered through a drying stage and then, the pressed body is ready for decoration. 
In particular, ceramic tiles can be traditionally glazed and/or decorated by digital ink-jet printing. Traditional glazes contain silica, frits, pigments, and other compounds with the function of opacifiers or melting additives [24]. On the other hand, the ink-jet decoration, which has been introduced during the last decades as a process innovation, has recently gained an increasing importance and application. This technology involves the use of fine-grained pigments dispersed in organic media, especially alcohols and glycols. Recent studies are focusing on the use of more sustainable aqueous media $[25,26]$. After the decoration step, the tiles are fired at temperatures up to $1150-1200{ }^{\circ} \mathrm{C}$. In the final stages, the product is mechanically treated in order to reach its final format and/or enhance its aesthetic appearance and it is lastly packed and ready to be sold.

The principal emission source of a ceramic tile production site is represented by the release of particulate matter (PM) during nearly all the stages of the production process. This is well expected because the ceramic production process is based on powder technology. In particular, the release of ceramic particles is mostly associated with the handling of raw materials and their physical transformations, above all the spray-drying and pressing stages. The released powder is taken up by aspirating systems at each of the working operations and driven through filtering treatments, before being discharged from the emission channels, or chimneys. With the exception of a limited number of plants employing a wet abatement, the most widely adopted filtering devices in the Italian ceramic district are fabric filter type [27]. Therefore, the PM separation is based on a physical treatment.

The firing of ceramic tiles is the most sensitive stage of the whole process from the emission point of view. The high temperatures reached during firing $\left(1000-1250{ }^{\circ} \mathrm{C}\right.$ as a function of selected raw materials) promote the sintering process, thus allowing raw material transformations. At this stage, several pollutants eventually present as impurities in the raw materials can be released. Emissions from kilns are thus additionally treated with chemical processes such as the use of calcium hydroxide $\left(\mathrm{Ca}(\mathrm{OH})_{2}\right)$ inside the filter boxes. This allows the capture of acidic compounds eventually present in the exhausted gasses (especially hydrofluoric acid generated by the release of fluoride $\left(\mathrm{F}^{-}\right)$ions that can be present in clay structures [28,29]). Another important pollutant potentially released during firing can be lead $(\mathrm{Pb})$. This element is practically absent inside the raw materials for ceramic bodies, but it can be found in some glaze formulations. The decomposition of the lead compounds releases lead oxide $(\mathrm{PbO})$, which can be blown out through the emission channels [30,31]. Luckily, the innovation in decoration technology has almost entirely eliminated the use of heavy metals, such as $\mathrm{Pb}$. Moreover, boron is nowadays used instead of lead in frits and glazes formulations under the form of boron oxide $\left(\mathrm{B}_{2} \mathrm{O}_{3}\right)$ or other boron-containing minerals [24].

The emission of organic compounds has also been detected during firing operations. These can be sourced from the use of some functional additives of organic nature (dispersing agents, deflocculants, opacifiers, etc.) especially in the decorating stages, rather than from the limited amounts of organic residues in the raw materials [25,32]. These organic compounds volatize inside the kilns producing volatile organic compounds (VOCs) as a result of their incomplete combustion into carbon dioxide, $\mathrm{CO}_{2}$. The presence of these kinds of pollutants in the emissions may lead to undesired odors in the local geographical areas of the production plants, impacting in this manner on people's comfort level. Post-combustion devices can be used in order to pursue the complete oxidation of the organic specimens.

Finally, fuel consumption used for the feed of kilns and spray-dryers, is largely accountable for the emissions of $\mathrm{NO}_{\mathrm{X}}$ and $\mathrm{CO}_{2}$ [33]. Nitrogen oxides $\left(\mathrm{NO}_{\mathrm{X}}\right.$ stands for a mixture of $\mathrm{NO}$ and $\left.\mathrm{NO}_{2}\right)$ are one of the principal chemical species coming almost entirely from human activities to be responsible of photochemical pollution. In addition, their hazardous action can be fostered by the presence of VOCs in the atmosphere [34]. On the other hand, sulfur (S) impurities and chlorides present in the raw materials for ceramic bodies accounts for acidic gasses, such as $\mathrm{SO}_{\mathbf{X}}$ and $\mathrm{HCl}$, especially the emissions from the kilns. These two pollutants are responsible, together with $\mathrm{NO}_{X}$, for acidic rain events [35]. 


\subsection{Environmental Indicators}

Data on pollution have been collected among Italian producers of ceramic tiles over a period of thirty years, starting from 1988 [36]. The data collection and relevant elaborations have been carried out by Centro Ceramico, in collaboration with the industry association Confindustria Ceramica and Emilia-Romagna region (Italy). The data were collected by 90 ceramic tile factories located in Emilia Romagna region, representing a very complete picture of the ceramic tile sector in Italy. The data have been processed in order to provide a great number of environmental indicators representing pollutants at the gaseous emissions. The constant update of these indicators during the years has allowed for tracking the trend of the sources responsible for the environmental impact of ceramic tiles production and has granted a portrait of the efforts made for the improvement of the sustainability in this industrial sector.

For the analysis carried out, the ceramic tile production process has been classified into 3 different classes:

- class 1: complete production cycle (as reported in Figure 2);

- class 2: complete production cycle + production of spray dried powder for other companies;

- class 3: partial production cycle involving only the steps from pressing and without considering spray-dried powders production.

Companies belonging to class 1 involve all the steps reported in Figure 2, from raw materials storage to the packaging of finished products. The extraction of raw materials is not included as they are mostly imported and managed by raw materials companies. Companies belonging to class 3 , with a partial production cycle, are usually smaller than companies belonging to class 2 .

To highlight the environmental impact of the tiles production, two important environmental indicators have been considered:

- $\quad \mathrm{EF}_{\mathrm{i}}\left[\mathrm{mg} / \mathrm{m}^{2}\right]$ or $\left[\mathrm{g} / \mathrm{m}^{2}\right]$ : emission factor of the "i-th" pollutant. It indicates the amount of pollutant released per square meter of tile produced.

- $\mathrm{R}_{\mathrm{i}}[\%]$ : recycling ratio for the "i-th" material. It indicates the ratio of water or solid waste recycled within the production plant.

The environmental parameters reported are considered as performance indicators. In this way, each contribution (expressed as emission factor) to the environmental impact is independent to the specific productive dimensions of each ceramic tiles plant. The emission factors have been expressed based on the mass flow for each pollutant $(\mathrm{kg} /$ year) and the effective tiles production per each year $\left(\mathrm{m}^{2} /\right.$ year). In particular, the mass flow data supplied by each company for any specific pollutant is the sum of the mass flows of that specific pollutant over all the emission points on the production site, according to the annual flow and working hours of each plant. This information has been provided by each production plant from the current Integrated Pollution and Prevention Control (IPPC) directives and in line with each specific Integrated Environmental Authorization (AIA) document [37]. The AIA document is an authorization released to factories by the competent Italian authorities on the basis of factory production capacities (the threshold value for ceramic plants amounts to 75 ton per day). In addition, AIA documents regulate the compliance to the IPPC directive at regional or provincial level and they act in a more severe manner by applying lower limit values for each pollutant.

All the data of total mass flows and recycling ratios are supplied by each company without relevant uncertainty. In this regard, the authors consider that it is not possible to associate uncertainty to the calculated environmental indicators. Additionally, the surveyed data are comprehensive of the different production specificities of each company and, for this reason, the values of the above-mentioned indicators should be considered as truly representative of the environmental impact of the Italian ceramic district.

The pollutants considered in the following sections are particulate matter (PM) (determined according to EN 13284-1:2003 and EN 13284-1:2017), fluorine (F) (according to ISTISAN 98/2 (DM 25/08/00 annex 2), lead (Pb) (according to ISTISAN 88/19-UNICHIM 723), volatile organic 
compounds (VOCs) (according to EN 12619:2013), aldehydes (ald) (according to EPA TO-11A), and nitrogen oxides $\left(\mathrm{NO}_{X}\right)$ (according to ISTISAN 98/2 (DM 25/08/00 annex. 1) [38-45]. In addition, waste management has been discussed through the evaluation of the quantity of water and solid material recycled within the ceramic tiles production. Carbon dioxide $\left(\mathrm{CO}_{2}\right)$ emissions have not been considered as they will be the topic of a next study, considering that $\mathrm{CO}_{2}$ emissions are also involved in the Emission Trading System (ETS) [46]. The trend for the emission factor of sulfur oxides has been omitted because of the scarcity of data. AIA directives do not require $\mathrm{SO}_{\mathrm{X}}$ emission values when natural gas is adopted as fuel for the spray-drying and firing stages as occurs in Italy. Currently, AIA directives do not require boron emissions as the limits in force, fixed by $10 \mathrm{mg} / \mathrm{m}^{2}$, are normally complied (in accordance with the regional council decision DGR 1159/2014 of the Emilia-Romagna region). The analytical determination of boron element required by the Italian regulations consists of its chemical determination inside the particulate matter sample collected at the emission points [47].

For each pollutant, a comparison between the value of the environmental indicator and the limits specified by the Italian BAT and the EU Ecolabel has been carried out when possible.

\section{Results}

\subsection{Pollutants by Gaseous Emissions}

All the reported data generally cover a period of 9 years from 2010 to 2018, except data for emission factor of particulate matter and fluorine element collected from 1996 to 2018, and data for lead emissions collected from 2005 and 2018. Figure 3 reports the trend for the emission factor $\left(\mathrm{EF}_{\mathrm{PM}}\right)$ of the most common pollutant produced by the ceramic sector: the particulate matter. The plot shows a significant reduction of the emitted PM along the years. A value of $4.4 \mathrm{~g} / \mathrm{m}^{2}$ was collectively recorded as mean value for the whole Italian tile production in the years 1996-1997. A decreasing trend is then observed, especially in the timespan ranging from 2005 to 2014. In the following years up to 2018, the $\mathrm{EF}_{\mathrm{PM}}$ shows modest changes with a nearly constant values (around $0.95,1.30$ and $0.35 \mathrm{~g} / \mathrm{m}^{2}$ for classes 1, 2 and 3, respectively). This trend shows that the most optimized abatement technologies are being currently employed by all the Italian ceramic tiles manufacturers and in recent years, very low values of $\mathrm{EF}_{\mathrm{PM}}$ have been recorded. In the BAT document for the Italian ceramic sector, the $\mathrm{EF}_{\mathrm{PM}}$ limit is $7.5 \mathrm{~g} / \mathrm{m}^{2}$, over five time higher than the highest values recorded in 2018, related to Class 2 , thus indicating an outstanding performance of the Sassuolo ceramic district. The noteworthy reduction of PM emission is also confirmed if the $\mathrm{EF}_{\mathrm{PM}}$ trend reported in Figure 3 is compared with the EU Ecolabel limit $\left(5.2 \mathrm{~g} / \mathrm{m}^{2}\right)$. It is interesting to note how $\mathrm{EF}_{\mathrm{PM}}$ for the three different production classes differs, but of an almost constant factor along the years. This is related to the fact that plants belonging to Class 2, which produce an excess of spray-dried powders to be sold, have to manage higher fluxes of raw materials for the same square meters of tiles manufactured, for example, in plants belonging to Class 1. Conversely, industrial plants belonging to Class 3 which buy the spray-dried powders, can avoid the initial production steps and, thus, exhibit lower values for the considered indicator. Indeed, the storage of raw materials, milling and spray-drying of the ceramic slurry are all stages widely affecting PM production.

The trend of the emission factor of fluorine $\left(\mathrm{EF}_{\mathrm{F}}\right)$, another major pollutant of the ceramic tiles production, is reported in Figure 4. This indicator takes into account all the chemical species of fluorine generated at the high temperatures inside the kiln. The recorded mean value of this pollutant for the years 1996-1997 was equal to $0.48 \mathrm{~g} / \mathrm{m}^{2}$. A decreasing trend of $\mathrm{EF}_{\mathrm{F}}$ is then clearly evident for Class 1 , 2 and 3, moving from $0.20,0.18$ and $0.165 \mathrm{~g} / \mathrm{m}^{2}$ in the years $2005-2007$, to $0.09,0.066$ and $0.07 \mathrm{~g} / \mathrm{m}^{2}$ in 2018, respectively. However, two main differences between the trends of $\mathrm{EF}_{\mathbf{P M}}$ and $\mathrm{EF}_{\mathbf{F}}$ can be observed. Firstly, a continuously decreasing tendency is more evident. This is due to the fact that the abatement efficiency for fluorine compounds depends on different variables; the emission of this pollutant can be handled by finer regulation on the concentration of calcium hydroxide inside the filters or by employing higher quality clays, which contain lower amounts of fluorine impurities. For this reason, 
continuous efforts are spent on the achievement of decreasing levels for this emission factor. Secondly, the values obtained during the whole timespan for the three production classes are comparable as these specific pollutant emissions are entirely ascribed to the firing stage. Lastly, the comparison with the Italian BAT and EU Ecolabel limit values $\left(0.6\right.$ and $0.2 \mathrm{~g} / \mathrm{m}^{2}$ respectively) confirms the vast efforts made by the Italian ceramic industry over the years in the management of fluorine emissions within the European context.

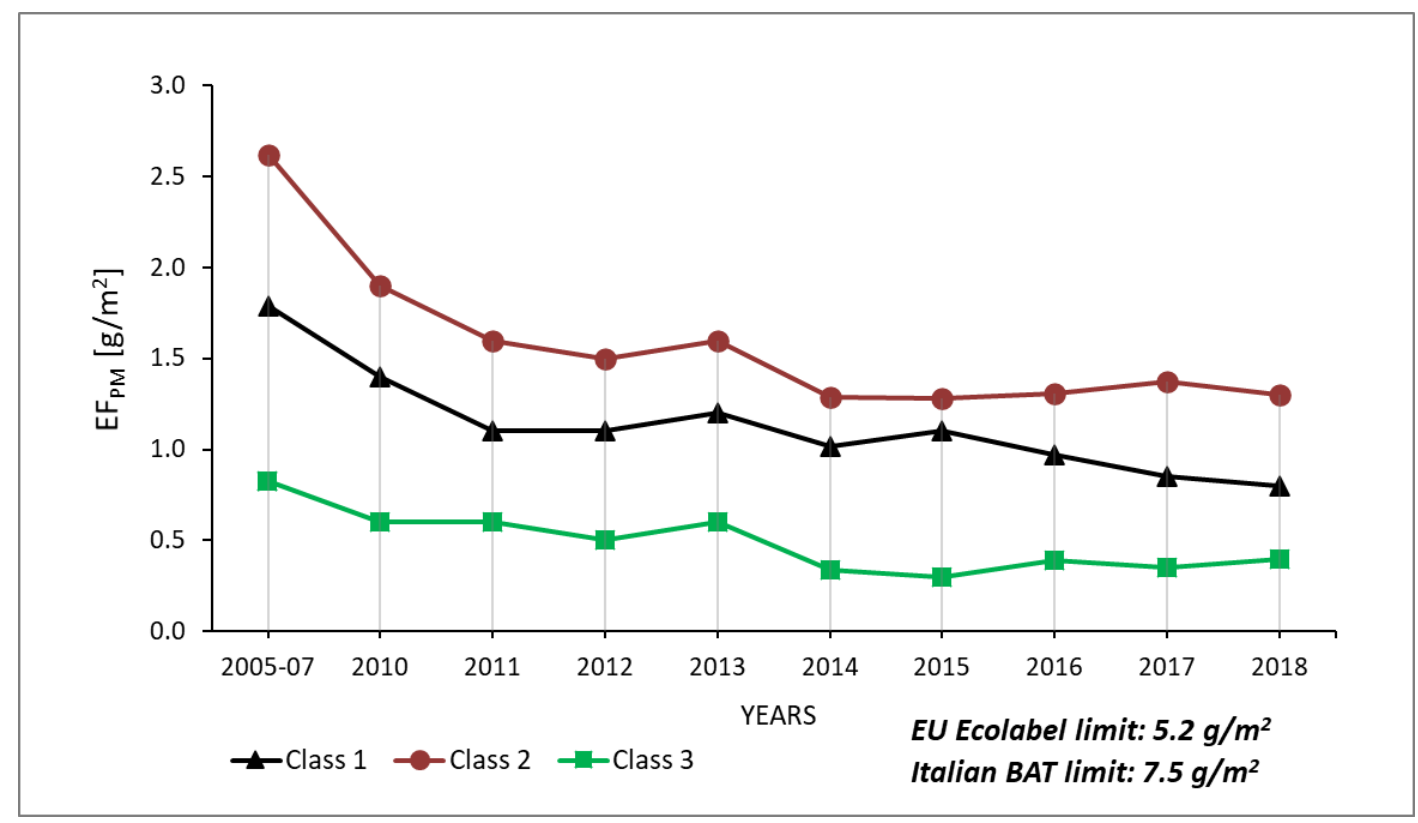

Figure 3. Trend for the emission factor of particulate matter, $\mathrm{EF}_{\mathrm{PM}}$, for the three production classes.

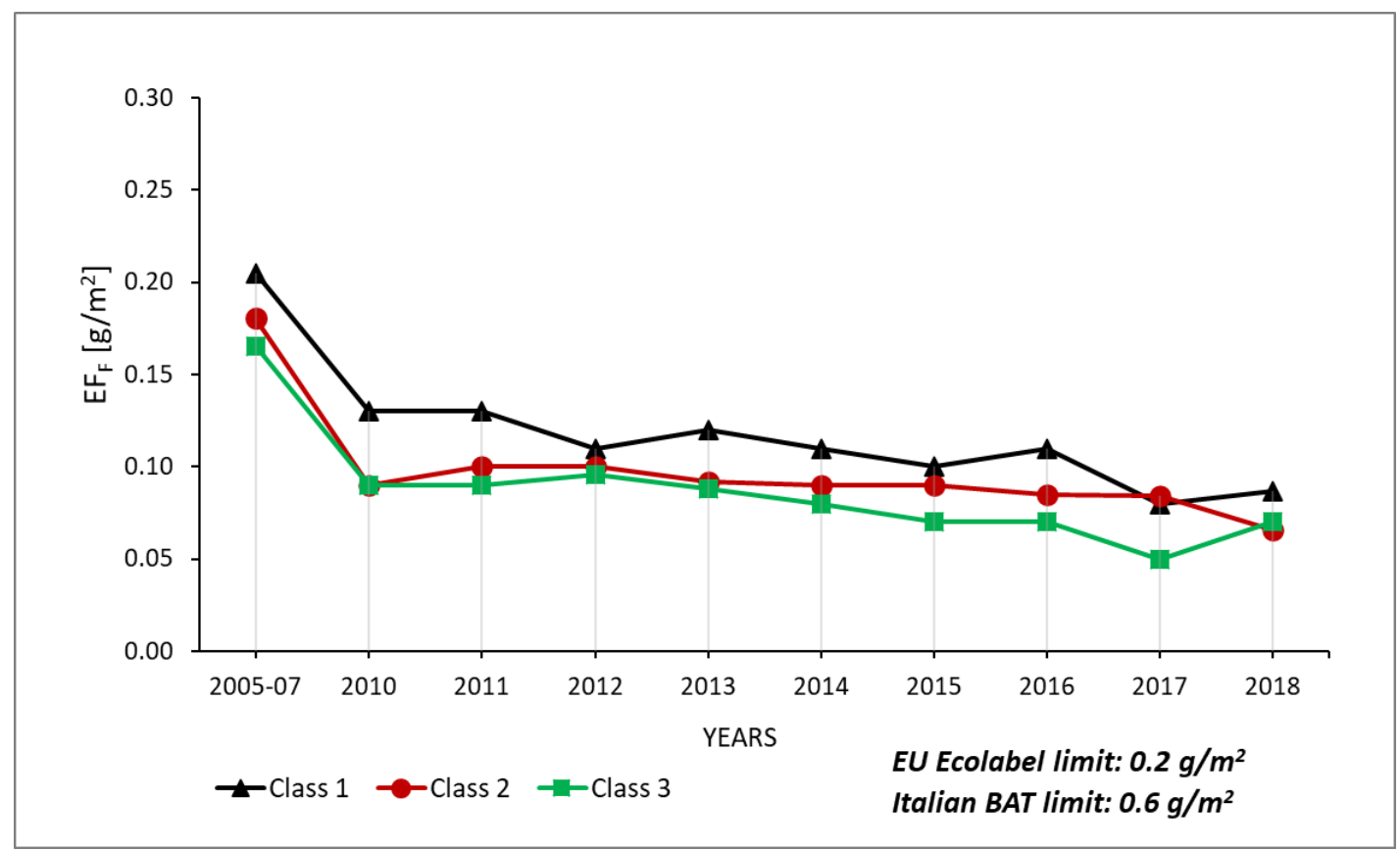

Figure 4. Trend for the emission factor of fluorine $\left(\mathrm{EF}_{\mathrm{F}}\right)$ for the three production classes.

The trend for the emission factor of lead $\left(\mathrm{EF}_{\mathrm{Pb}}\right)$ is reported in Figure 5. The values are reported from 2005 because of the absence of data on lead emission per square meters of tiles produced in previous years. However, the value recorded at the end of the $1990 \mathrm{~s}$, that was over $100 \mathrm{mg} / \mathrm{m}^{2}$, 
was found from data reported in a previous environmental survey [15]. Such a high level was caused by an extensive use of lead-containing glaze. The impressive decrease of $\mathrm{Pb}$ emissions until the current situation $\left(\mathrm{EF}_{\mathrm{Pb}}\right.$ around $\left.1 \mathrm{mg} / \mathrm{m}^{2}\right)$ is related to the almost complete change of raw materials used for glazes and the adoption of alternative pigments, containing negligible values of heavy metals (included $\mathrm{Pb}$ ). This is demonstrated by the noteworthy decrease of $\mathrm{EF}_{\mathrm{Pb}}$ in the period 2005-2010. The decreasing trend of $\mathrm{EF}_{\mathrm{Pb}}$ has continued in the following years with some fluctuations, however the large diffusion of digital ink-jet decoration in 2014 has certainly contributed to lowering $\mathrm{EF}_{\mathrm{Pb}}$ for all the three classes. The success in the abatement of lead is highlighted by the comparison with the concentration limit set in the Italian BAT $\left(50 \mathrm{mg} / \mathrm{m}^{2}\right)$, whereas Ecolabel legislation does not consider an emission limit for such important pollutant.

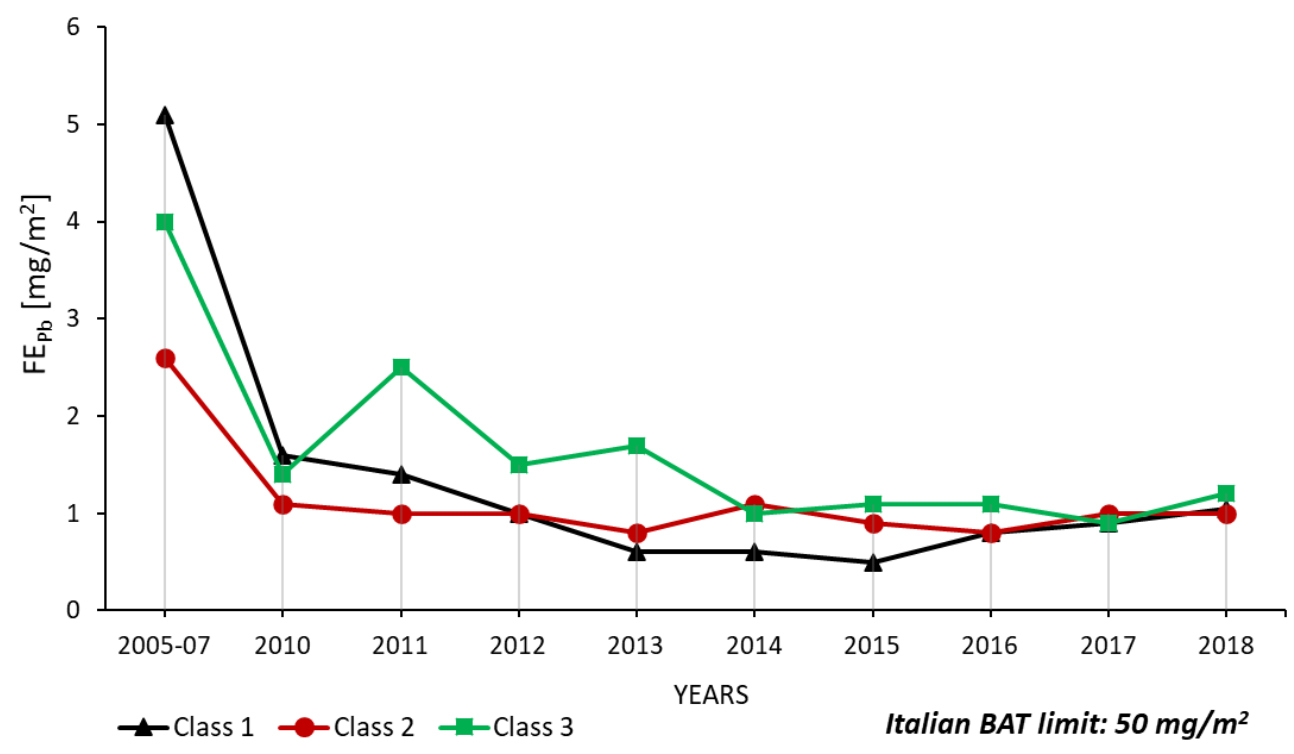

Figure 5. Trend for the emission factor of lead $\left(\mathrm{EF}_{\mathrm{Pb}}\right)$ for the three production classes.

Figure 6 reports the trends for the emission factors of $\mathrm{VOCs}_{\mathrm{S}}\left(\mathrm{EF}_{\mathrm{VOC}}\right.$, Figure $\left.6 \mathrm{a}\right)$ and aldehydes $\left(\mathrm{EF}_{\text {ald }}\right.$, Figure $\left.6 \mathrm{~b}\right)$. These emissions are related to various causes such as the oxidant or reductive atmosphere inside the kilns, the chemical nature of the additives and the presence of post-combustion devices [48], thus it is often difficult to find reproducible concentration values. Even if aldehydes are considered volatile organic compounds, for the production of ceramic tiles they are subjected to specific concentration limits on the basis of each individual AIA document [37]. However, the concentrations of VOCs detected at the emission points always includes the aldehyde contribution.

Both plots of Figure $6 \mathrm{a}, \mathrm{b}$ exhibit the same trend. The steep increase, culminating in $2013\left(1.0 \mathrm{~g} / \mathrm{m}^{2}\right.$ for VOCs and $0.28 \mathrm{~g} / \mathrm{m}^{2}$ for aldehydes, for Class 2 and 3 respectively), can be easily explained by the progressive adoption of digital ink-jet printing decoration. These systems provide impressive aesthetic effects on the ceramic surface, with the drawback of a large use of organic additives compared to traditional glazing techniques. In 2014-2015, however, the trend for both $\mathrm{EF}_{\mathrm{VOCs}}$ and $\mathrm{EF}_{\mathrm{ald}}$ decreased reaching stable values (about 0.75 and $0.15 \mathrm{~g} / \mathrm{m}^{2}$ for VOCs and aldehydes respectively), especially for $\mathrm{EF}_{\mathrm{VOC}}$, according to the improvements carried out in digital decoration to replace organic media with aqueous ones [26].

In this case, there are no limits in force in the current versions of Italian BAT and Ecolabel documents as the detection of VOCs and aldehydes in the emissions assessment of ceramic tiles plants is a recent issue and the legislation has not been updated yet. 


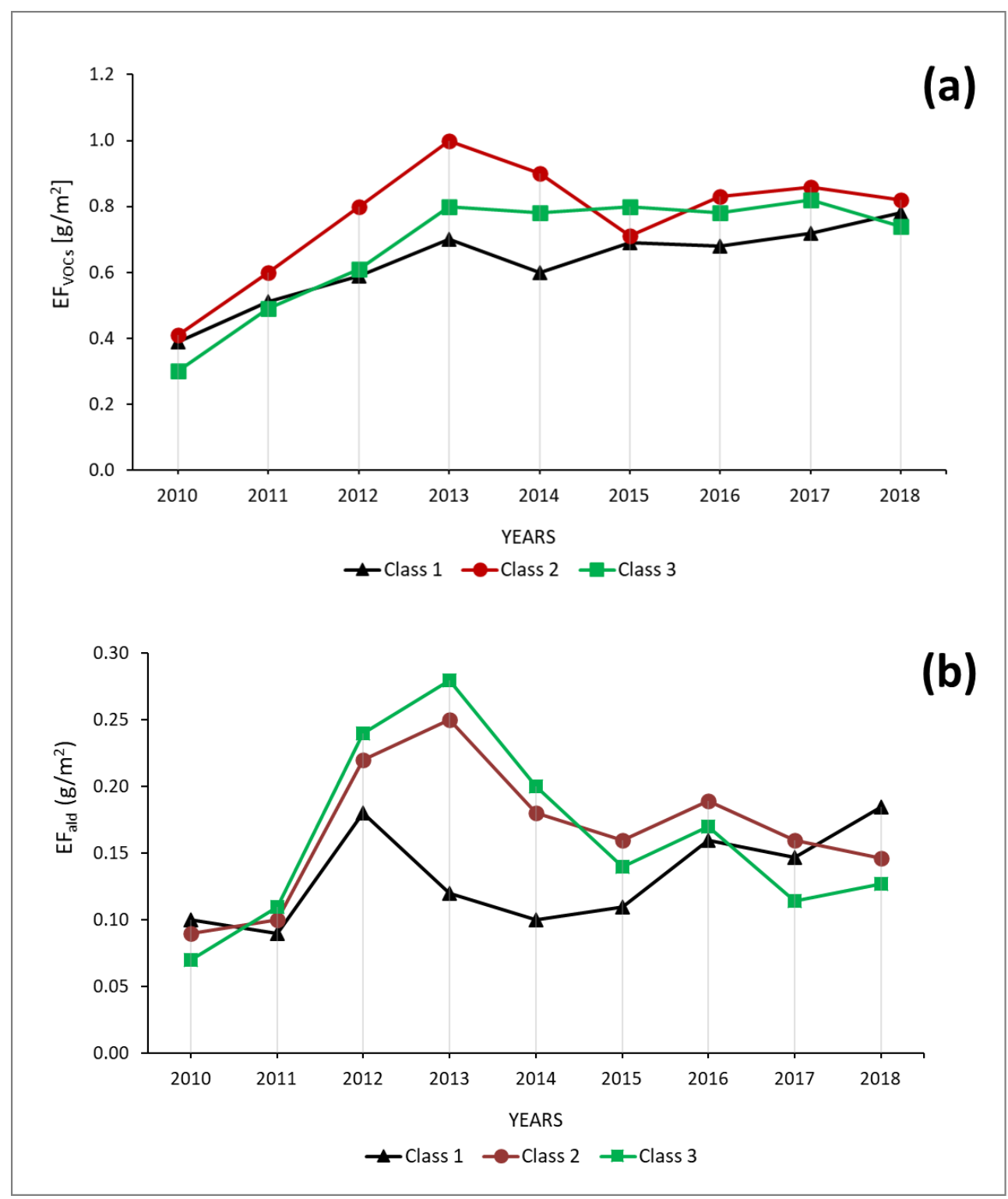

Figure 6. Trend for the emission factor of VOCs $\left(\mathrm{EF}_{\mathrm{VOCs}}\right)(\mathbf{a})$ and aldehydes $\left(\mathrm{EF}_{\mathrm{ald}}\right)(\mathbf{b})$ for the three production classes.

The trend for the emission factor of nitrogen oxides $\left(\mathrm{EF}_{\mathrm{NOx}}\right)$ in the period between 2010 and 2018 show a complex behavior (Figure 7). In particular, a steady increase has been recorded between 2010 and 2014 for Classes 2 and $3\left(4.3 \mathrm{~g} / \mathrm{m}^{2}\right.$ and $2.3 \mathrm{~g} / \mathrm{m}^{2}$ in 2014 respectively), while over the last period a stable trend is observed. However, the $\mathrm{EF}_{\mathrm{NOx}}$ values for Class 2 have been increased again since 2016. This is in line with the ceramic tile market's innovations in more recent years. In fact, the ceramic tiles production has recently shifted towards products characterized by larger dimensions and higher thicknesses. The amount of spray-dried powders produced for such products implies an increment of the working hours of the spray-drying machineries and, thus, a consequent increase in fuel consumption and $\mathrm{NO}_{x}$ emissions (especially for Class 2). The trends for Class 1 and Class 2 are almost comparable except for 2010 and 2014 years $\left(6.3 \mathrm{~g} / \mathrm{m}^{2}\right.$ for Class 1 in 2014). The overall increasing progression can thus be ascribed to product innovations. The fluctuations, conversely, may be explained by inconstant market demand of those years, preventing a constant production and affecting in this manner the process optimization of the thermal machineries. The EU Ecolabel legislation sets a rigorous limit for $\mathrm{NO}_{\mathrm{x}}$ of $2.5 \mathrm{~g} / \mathrm{m}^{2}$ regarding only the firing stage. The $\mathrm{EF}_{\mathrm{NOx}}$ values for Class 3 are under the 
limit for the whole considered period, whereas for Class 1 and 2 the comparison with the limit cannot be performed as $\mathrm{EF}_{\mathrm{NOx}}$ includes the total emissions of kilns and spray-drying stage.

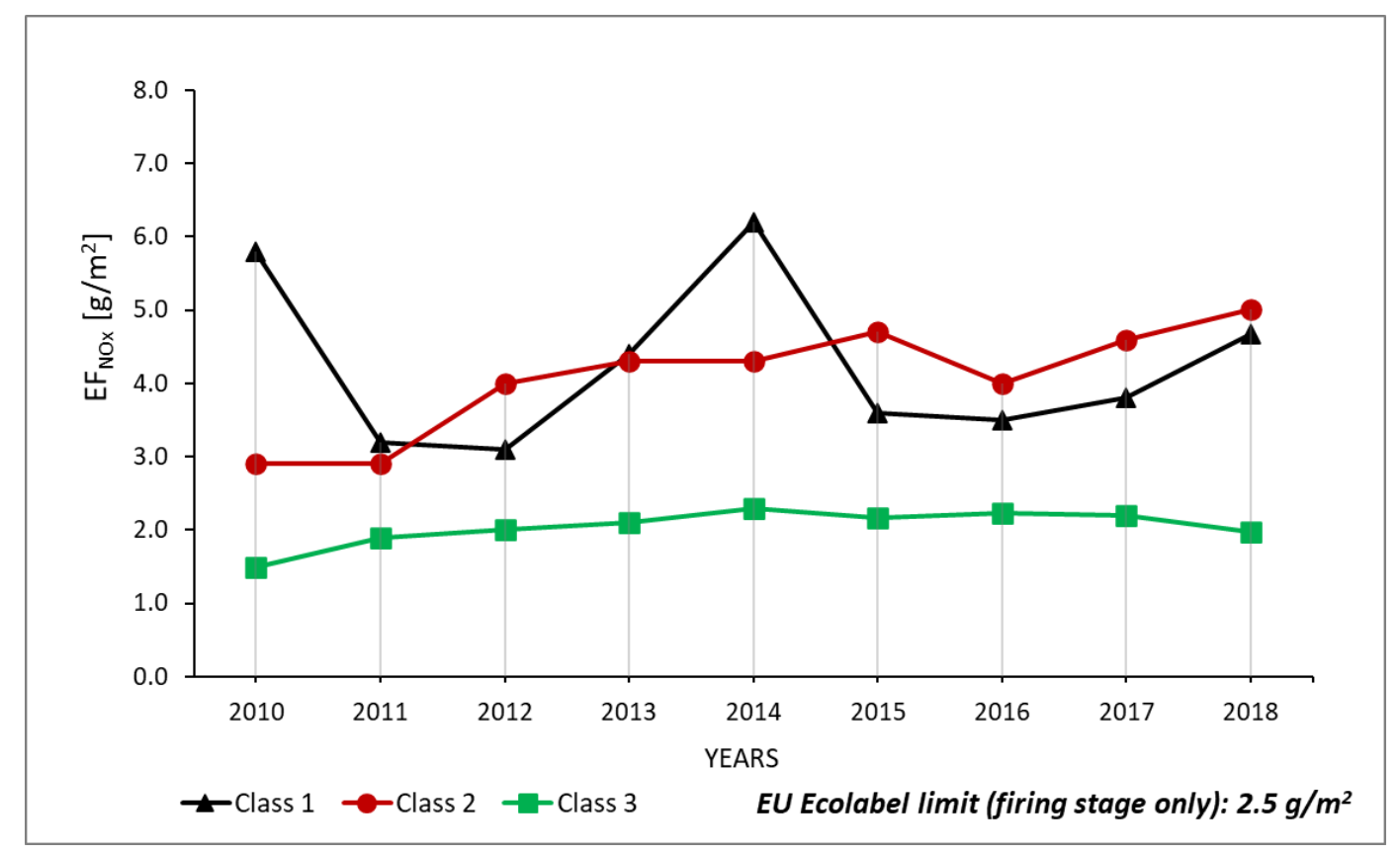

Figure 7. Emission trend for the emission factors for $\mathrm{NO}_{\mathrm{x}}\left(\mathrm{EF}_{\mathrm{NOx}}\right)$.

\subsection{Water and Waste Management}

Recycling and reuse of materials are fundamental missions for the Italian ceramic tile industry. Water is almost completely recovered within the production process after some purification steps. Recycled water is used for all the working operations which do not necessitate high levels of purity, as milling and spray-drying phases and washing of machineries and facilities. Water recycling is made possible by the absence of hazardous elements in the waste waters. However, water coming from glaze preparation and decoration phase (frits and pigments treatments) cannot be easily recycled due to the presence of ions in the used solutions. Figure 8 shows the water balance inside a ceramic plant; the main sources of waste waters outlet are represented by the vapor of the gaseous effluents from the firing and by the water involved in the spray-drying stages.

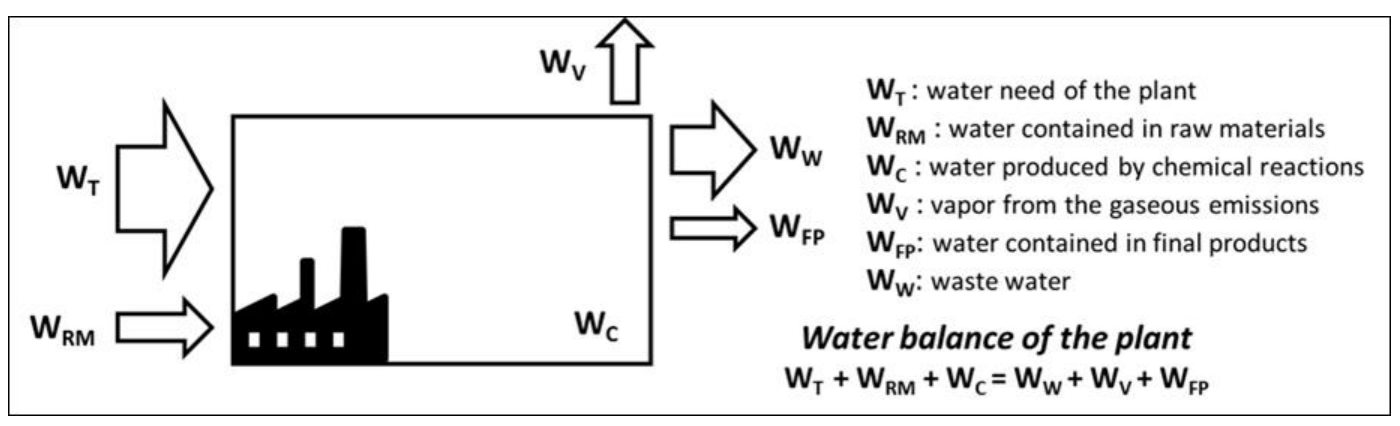

Figure 8. Scheme of the water balance of a ceramic tile plant.

The values for the $\mathrm{R}_{\mathrm{H} 2 \mathrm{O}}$ indicator reported in Figure 9 show the percentages of water recycled for the three production classes. The reference values for the recycling ratio of water set by the EU Ecolabel and the Italian BAT legislations are $90 \%$ and 50\% respectively. The trend highlights an optimized management of water used in ceramic tile plants. Values higher than $100 \%$ (as reported for Class 2) are due to the tendency of certain plants to collect wastewaters from other production sites. This is 
related to the fact that production plants belonging to Class 2, producing an excess of spray-dried powders, can recycle high amounts of water in a process that does not require high level of water purity. In fact, the rheology of the ceramic slurry, even if sensitive to flocculation and aggregation events, can always be tailored by adding low-cost additives, such as polyphosphates [32].

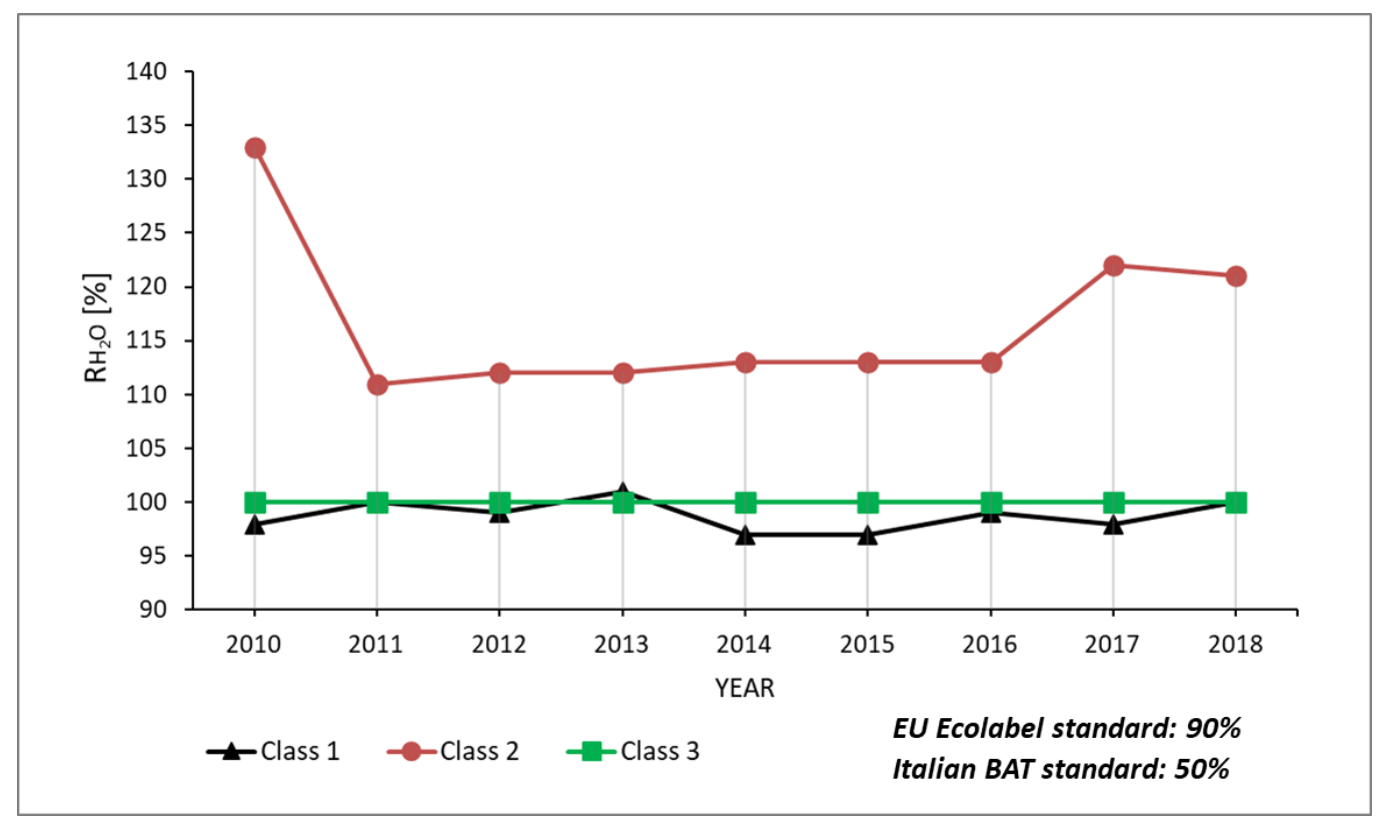

Figure 9. Trend for the recycling ratio of water $\left(\mathrm{R}_{\mathrm{H} 2 \mathrm{O}}\right)$. The data for all the three production classes are reported.

When a complete water recycling cannot be pursued, wastewaters are filtered and chemically treated with coagulants and flocculants to achieve an optimum degree of clarification. The obtained ceramic sludges may eventually be landfilled or disposed for the appropriate inertization treatment if the level of hazardous substances exceeds the legal limits. However, also these sludges can be recycled within the production process, as reported in the scientific literature [49,50].

Another important parameter for the sustainability of a ceramic tile production plant is the recycling ratio of solid waste. This environmental indicator considers the discharged green and fired tiles as well as ceramic powders coming from final surface treatment operations. The remaining waste sources cannot be considered in this data collection because of the existence of a proper legislation regulating both their recycling and their disposal. However, the mentioned materials represent the main solid wastes produced in ceramic tile plants. Green tiles, that have been discharged from the production process, are easily recycled inside the mills for the preparation of the ceramic slurry, thanks to the similar mineralogical composition. A different recycling management occurs for fired materials; cracked or deformed tiles that have already been fired and the ceramic powder coming from final surface treatments as squaring or smoothing, are usually employed in small amounts in the body formulations [51]. Indeed, their introduction in the mix shall be carefully monitored in order to avoid rheology variations of the ceramic slurry and undesired shrinkage in the new production.

Figure 10 highlights the values for the recycling ratio of solid waste, $R_{S w}$, over a period of 9 years. The trends demonstrate how a complete recycle for the solid waste is accomplished for all the three production classes. As it happens for the water management, the plants belonging to Class 2 show values of the indicator always higher than $100 \%$ as they usually collect solid ceramic wastes from other ceramic industrial plants. This also happens for industrial plants belonging to Class 1 but to a minor extent. The reference limits for the recycling ratio of solid waste set by the EU Ecolabel and the Italian BAT, of $85 \%$ and $50 \%$ respectively, are always largely overcome. 


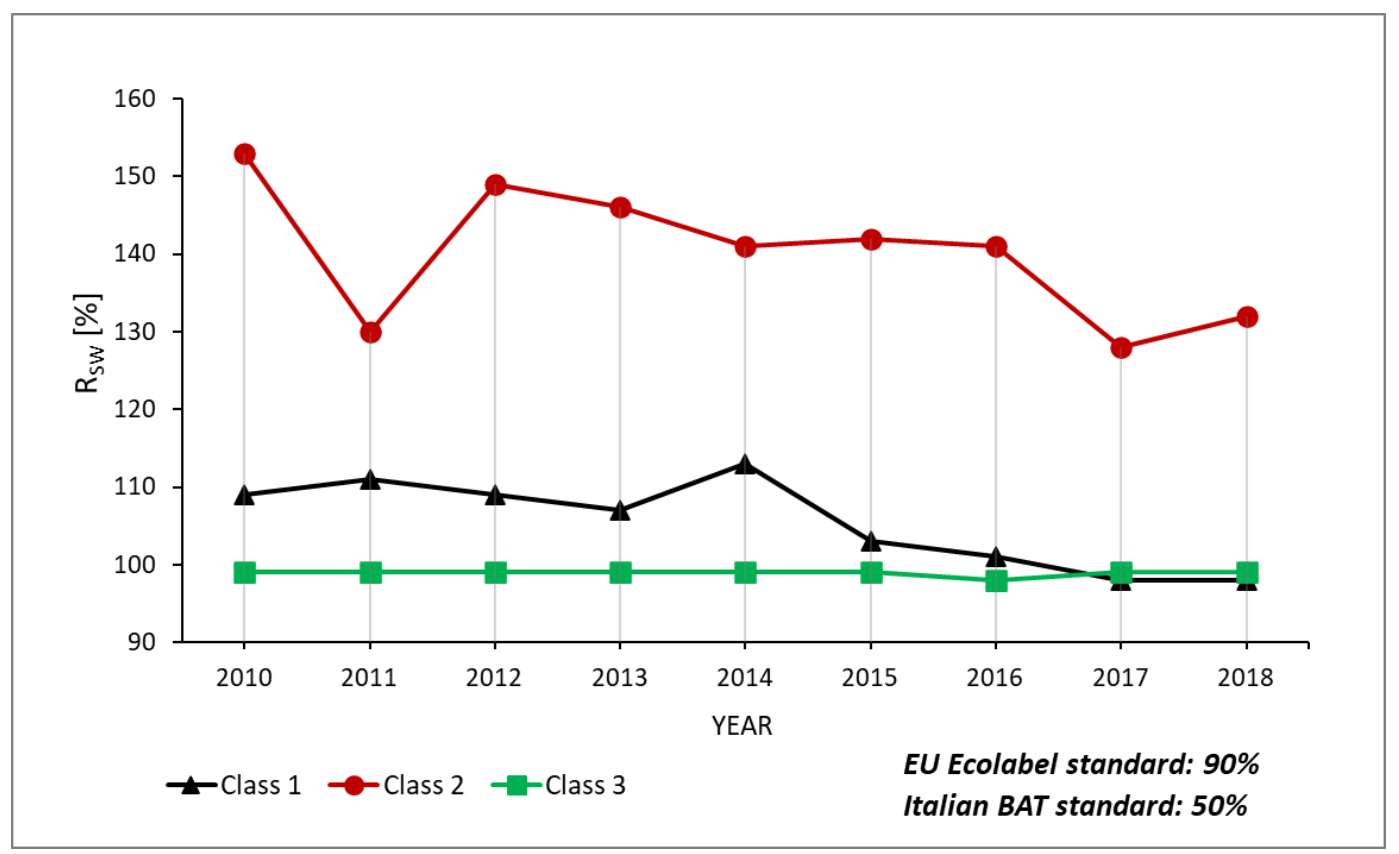

Figure 10. Trend for the recycling ratio of solid waste $\left(R_{S W}\right)$. Data for all the three production classes are reported.

\section{Conclusions}

The environmental impact of the Italian ceramic tiles production has been reported and discussed in this study. Data relating to the main pollutants of gaseous emissions, the water and solid waste management have been reported, considering a sample of 90 ceramic plants in Emilia-Romagna region over a period of more than 9 years. For specific pollutants (particulate matter, fluorine and lead elements), the reported data include a larger period.

The main results can be summarized as follows:

- over the last two decades, the concentration of particulate matter, fluorine and lead emitted by ceramic tile plants continuously decreased. The innovation in the production process technology have largely contributed to reach such excellent result. The concentration levels for each of the three pollutants are lower compared to the limit values reported in the Best Available Techniques (BAT) document.

- The collected data for the emission factor of volatile organic compounds (VOCs) and aldehydes cannot be compared to any limit because of the absence of such references in the Italian and European legislations. The future versions of the EU Ecolabel and ceramic BRef will probably take into account specific emission limits for these pollutants. The current situation shows that innovation in decoration is taking care to lower these types of emissions by increase the use of aqueous media.

- The trend for the emission factor of nitrogen oxides showed a modest but constant increase over the years. This is probably related to the higher thicknesses of new ceramic tiles recently presented in the market. The EU Ecolabel limit set for the emissions from firing operations has always been complied during the considered period.

- The recycling of water and solid waste are widely and successfully adopted within the Italian ceramic tiles productive sites. The virtuous values recorded for these environmental indicators demonstrate the high attention to recycling and sustainability policies performed by the ceramic industry.

The data collection and relevant elaborations reveal the strong attention to the environment of the Italian ceramic tile industry. The results obtained in this study are relevant for two main reasons: 
firstly, they attest, along the years, the efforts addressed to the improvement of the sustainability of the Italian ceramic production, and secondly, they demonstrate the success of the continuous collaboration between all the involved parties: the Emilia-Romagna region, the environmental agencies (ARPA Emilia Romagna), the research institutions (University of Bologna and Centro Ceramico) and the industries and their association (Confindustria Ceramica).

Author Contributions: Conceptualization, G.B. (Giuliana Bonvicini) and M.C.B.; Data curation, G.B. (Giacomo Boschi); Formal analysis, G.M.; Methodology, G.B. (Giacomo Boschi); Supervision, M.C.B.; Writing — original draft, G.B. (Giacomo Boschi); Writing—review \& editing, G.M., G.B. (Giuliana Bonvicini) and M.C.B. All authors have read and agreed to the published version of the manuscript.

Funding: This research was partially funded by Confindustria Ceramica (Italian Ceramic Industry Association).

Acknowledgments: The authors wish to thank Eng. Rossano Resca for his support in sharing his deep knowledge on the specific topic of this paper.

Conflicts of Interest: The authors declare no conflict of interest.

\section{References}

1. Brundtland, G. Report of the World Commission on Environment and Development: Our Common Future; United Nations General Assembly Document A/42/427. Available online: https://sustainabledevelopment. un.org/milestones/wced (accessed on 14 November 2020).

2. Pacheco-Torgal, F.; Cabeza, L.F.; Labrincha, J.; DeMagalhães, A. Eco-Efficient Construction and Building Materials: Life Cycle Assessment (LCA), Eco-Labelling and Case Studies; Woodhead Publishing Ltd.: Cambridge, UK, 2014; pp. 1-617.

3. Azhar, S.; Carlton, W.A.; Olsen, D.; Ahmad, I. Building information modeling for sustainable design and LEED ${ }^{\circledR}$ rating analysis. Autom. Constr. 2011, 20, 217-224. [CrossRef]

4. Ma, Z.; Cooper, P.; Daly, D.; Ledo, L. Existing building retrofits: Methodology and state-of-the-art. Energy Build. 2012, 55, 889-902. [CrossRef]

5. Santamouris, M. Cooling the cities-A review of reflective and green roof mitigation technologies to fight heat island and improve comfort in urban environments. Sol. Energy 2014, 103, 682-703. [CrossRef]

6. Mattoni, B.; Guattari, C.; Evangelisti, L.; Bisegna, F.; Gori, P.; Asdrubali, F. Critical review and methodological approach to evaluate the differences among international green building rating tools. Renew. Sustain. Energy Rev. 2018, 82, 950-960. [CrossRef]

7. Busani, G.; Palmonari, C.; Timellini, G. Piastrelle Ceramiche e Ambiente: Emissioni Gassose, Acque, Fanghi, Rumore; EDI.CER. SPA: Sassuolo, Italy, 1995.

8. Timellini, G.; Resca, R.; Bignozzi, M.C. Ceramic Industry Air Quality. Emissions into the Atmosphere from Ceramic Tile Processes. In Comprehensive Analytical Chemistry; de la Guardia, M., Armenta, S., Eds.; Elsevier: Amsterdam, The Netherlands, 2016; Volume 73, pp. 707-729.

9. Indagini Statistiche Sull'industria Italiana; Confindustria Ceramica: Sassuolo, Italy, 2019.

10. World Production and Consumption of Ceramic Tiles, 7th ed.; Acimac Research Department: Baggiovara, Italy, 2019.

11. Minguillón, M.C.; Querol, X.; Alastuey, A.; Monfort, E.; Mantilla, E.; Sanz, M.J.; Sanz, F.; Roig, A.; Renau, A.; Felis, C.; et al. PM10 speciation and determination of air quality target levels. A case study in a highly industrialized area of Spain. Sci. Total Environ. 2007, 372, 382-396. [CrossRef]

12. Minguillón, M.C.; Monfort, E.; Querol, X.; Alastuey, A.; Celades, I.; Vicente Miró, J. Effect of ceramic industrial particulate emission control on key components of ambient PM10. J. Environ. Manag. 2009, 90, 2558-2567. [CrossRef]

13. Minguillon, M.C.; Monfort, E.; Escrig, A.; Celades, I.; Guerra, L.; Busani, G.; Sterni, A.; Querol, X. Air quality comparison between two European ceramic tile clusters. Atmos. Environ. 2013, 74, 311-319. [CrossRef]

14. Palmonari, C. Inquinamento Atmosferico da Industrie Ceramiche: Studio di un Comprensorio: Sassuolo; Centro Ceramico: Bologna, Italy, 1979.

15. Piastrelle di Ceramica e Refrattari-Rapporto Integrato 1998-Ambiente, Energia, Sicurezza-Salute, Qualità; Assopiastrelle-Snam: Sassuolo, Italy, 1998. 
16. $2^{\circ}$ Rapporto Integrato per il Settore delle Piastrelle di Ceramica: Ambiente, Energia, Sicurezza-Salute, Qualità, Responsabilità Sociale d'Impresa; Confindustria Ceramica: Sassuolo, Italy, 2008.

17. Barbieri, C.; Sterni, A.; Torreggiani, L. Ecoscienza; Arpae Emilia-Romagna: Bologna, Italy, 2018; Volume 2, pp. $44-45$.

18. Best Available Techniques in the Ceramic Manufacturing Industry; European Commission: Sevilla, Spain, 2007.

19. Commission Decision of 9 July 2009 establishing the ecological criteria for the award of the Community eco-label to hard coverings. Off. J. Eur. Union 2009, 208/21, 115-132.

20. Il Ministro Dell'ambiente e Della Tutela Del Territorio E Del Mare. Emanazione di Linee Guida per L'individuazione e L'utilizzazione delle Migliori Tecniche Disponibili, in Materia di Fabbricazione di Vetro, Fritte Vetrose e Prodotti Ceramici, per le Attività Elencate Nell'allegato I del D. Lgs. 59. 2005. Available online: https://www.ambientediritto.it/Legislazione/INQUINAMENTO/2007/dm_29gen2007_vetro.htm (accessed on 14 November 2020).

21. Manfredini, T.; Pellacani, G.; Romagnoli, M.; Pennisi, L. Porcelainized Stoneware Tile. Am. Ceram. Soc. Bull. 1995, 74, 76-79.

22. Dondi, M.; Raimondo, M.; Zanelli, C. Clays and bodies for ceramic tiles: Reappraisal and technological classification. Appl. Clay Sci. 2014, 96, 91-109. [CrossRef]

23. Dondi, M.; Guarini, G.; Conte, S. Deposits, composition and technological behavior of fluxes for ceramic tiles. Period. Miner. 2019, 88, 235-257. [CrossRef]

24. Casasola, R.; Ma Rincón, J.; Romero, M. Glass-ceramic glazes for ceramic tiles: A review. J. Mater. Sci. 2012, 47, 553-582. [CrossRef]

25. Pan, Z.; Wang, Y.; Huang, H.; Ling, Z.; Dai, Y.; Ke, S. Recent development on preparation of ceramic inks in ink-jet printing. Ceram. Int. 2015, 41, 12515-12528. [CrossRef]

26. Güngör, G.L.; Kara, A.; Gardini, D.; Blosi, M.; Dondi, M.; Zanelli, C. Ink-jet printability of aqueous ceramic inks for digital decoration of ceramic tiles. Dye. Pigment. 2016, 127, 148-154. [CrossRef]

27. Breedveld, L.; Timellini, G.; Casoni, G.; Fregni, A.; Busani, G. Eco-efficiency of fabric filters in the Italian ceramic tile industry. J. Clean Prod. 2007, 15, 86-93. [CrossRef]

28. Bonvicini, G.; Fregni, A.; Palmonari, C. Fluorine Compounds from Industrial Sources: The Case of Ceramic Industries. In Fluorine and the Environment: Atmospheric Chemistry, Emissions, and Lithosphere, Volume 1; Tressaud, A., Ed.; Elsevier: Amsterdam, The Netherlands, 2006; pp. 225-249.

29. Monfort, E.; Garcia-Ten, J.; Celades, I.; Gazulla, M.F.; Gomar, S. Evolution of fluorine emissions during the fast firing of ceramic tile. Appl. Clay Sci. 2008, 38, 250-258. [CrossRef]

30. Shackelford, J.; Doremus, R.H. (Eds.) Ceramic and Glass Materials: Structure, Properties and Processing; Springer: New York, NY, USA, 2008.

31. Jarup, L. Hazards of heavy metal contamination. Br. Med. Bull. 2003, 68, 167-182. [CrossRef]

32. Vitali, S.; Giorgini, L. Overview of the Rheological Behaviour of Ceramic Slurries. FME Trans. 2019, 47, $42-47$. [CrossRef]

33. Ros-Dosda, T.; Fullana-i-Palmer, P.; Mezquita, A.; Masoni, P.; Monfort, E. How can the European ceramic tile industry meet the EU's low-carbon targets? A life cycle perspective. J. Clean Prod. 2018, 199, 554-564. [CrossRef]

34. Brusseau, M.L.; Matthias, A.D.; Comrie, A.C.; Musil, S.A. Atmospheric Pollution. In Environmental and Pollution Science, 3rd ed.; Brusseau, M.L., Pepper, I.L., Gerba, C.P., Eds.; Academic Press: Cambridge, MA, USA, 2019; pp. 293-309.

35. Monfort, E.; Celades, I.; Gomar, S.; Rueda, F.; Martinez, J. Characterisation of acid pollutant emissions in ceramic tile manufacture. Bol. Soc. Esp. Ceram. Vidr. 2011, 50, 179-184. [CrossRef]

36. Palmonari, C.; Timellini, G. Air pollution from the ceramic industry: Control experiences in the Italian ceramic tile industry. Am. Ceram. Soc. Bull. 1989, 68, 1464-1469.

37. Directive 2010/75/EU of the European Parliament and of the Council of 24 November 2010 on Industrial Emissions (Integrated Pollution Prevention and Control), Official Journal of the European Union. 2010. Available online: https://eur-lex.europa.eu/eli/dir/2010/75/oj (accessed on 14 November 2020).

38. Stationary Source Emissions-Determination of Low Range Mass Concentration of Dust-Manual Gravimetric Method; CEN: Brussels, Belgium, 2003.

39. Stationary Source Emissions-Determination of Low Range Mass Concentration of Dust_Part 1: Manual Gravimetric Method; CEN: Brussels, Belgium, 2017. 
40. Rilevamento delle Emissioni in Flussi Gassosi Convogliati di Composti Organici del Cloro e del Fluoro Sotto Forma di Gas e Vapore Espressi Rispettivamente Come HCl e HF; Istituto Superiore di Sanità: Rome, Italy, 2000.

41. Campionamento e Dosaggio di Microinquinanti in Flussi Gassosi Convogliati; Istituto Superiore di Sanità: Rome, Italy, 1988.

42. Misure Alle Emissioni-Flussi Gassosi Convogliati-Solubilizzazione di Materiale Particellare per la Determinazione dei Metalli Mediante Tecniche di Spettrometria (EM/22); UNICHIM: Milano, Italy, 1986.

43. Stationary Source Emissions-Determination of the Mass Concentration of Total Gaseous Organic Carbon-Continuous Flame Ionisation Detector Method; CEN: Brussels, Belgium, 2013.

44. EPA TO-11A, Determination of Formaldehyde in Ambient Air Using Adsorbent Cartridge Followed by High Performance Liquid Chromatography (HPLC); Waters Corporation: Milford, MA, USA, 2008.

45. Rilevamento Delle Emissioni in Flussi Gassosi Convogliati di Ossidi di Zolfo e Ossidi di Azoto Espressi Rispettivamente Come $\mathrm{SO}_{2}$ e $\mathrm{NO}_{2}$; Istituto Superiore di Sanità: Rome, Italy, 2000.

46. Directive (EU) 2018/410 of the European Parliament and of the Council of 14 March 2018 Amending Directive 2003/87/EC to Enhance Cost-Effective Emission Reductions and Low-Carbon Investments, and Decision (EU) 2015/1814; European Parliament, Council of the European Union: Brussels, Belgium, 2018.

47. Indicazioni Generali Sulla Semplificazione del Monitoraggio e Controllo Degli Impianti Soggetti ad Autorizzazione Integrata Ambientale (AIA) ed in Particolare Degli Impianti Ceramici; Bollettino Ufficiale della Regione Emilia-Romagna: Bologna, Italy, 2014.

48. Ferrari, G.; Zannini, P. VOCs monitoring of new materials for ceramic tiles decoration: GC-MS analysis of emissions from common vehicles and inkjet inks during firing in laboratory. Bol. Soc. Esp. Cerám. Vidr. 2017, 56, 226-236. [CrossRef]

49. Manfredini, T.; Marzola, G.; Nunziello, S.; Pellacani, G.; Pozzi, P.; Tubertini, O. The Recycling of Ceramic Sludges in the Production Process-An Option for Ceramic Tile Factories to Reach Zero Pollution. Environ. Technol. 1991, 12, 927-934. [CrossRef]

50. Nandi, V.S.; Raupp-Pereira, F.; Montedo, O.R.K.; Oliveira, A.P.N. The use of ceramic sludge and recycled glass to obtain engobes for manufacturing ceramic tiles. J. Clean Prod. 2015, 86, 461-470. [CrossRef]

51. Rambaldi, E.; Esposito, L.; Tucci, A.; Timellini, G. Recycling of polishing porcelain stoneware residues in ceramic tiles. J. Eur. Ceram. Soc. 2007, 27, 3509-3515. [CrossRef]

Publisher's Note: MDPI stays neutral with regard to jurisdictional claims in published maps and institutional affiliations.

(C) 2020 by the authors. Licensee MDPI, Basel, Switzerland. This article is an open access article distributed under the terms and conditions of the Creative Commons Attribution (CC BY) license (http://creativecommons.org/licenses/by/4.0/). 